\title{
HARGA PROPERTI RESIDENSIAL DAN KREDIT PERBANKAN DI INDONESIA; ANALISIS AGREGAT DAN DIS-AGREGAT
}

Vol. 15 - No. 1

April 2015

\author{
Rahmat Heru Setianto \\ Fakultas Ekonomi dan Bisnis, Universitas Airlangga \\ rahmat.heru@feb.unair.ac.id
}

\begin{abstract}
ABSTRAK
Penelitian ini melihat hubungan janka panjang antara harga properti residensial dengan kredit perbankan di Indonesia. Selain menggunakan harga agregat, penelitian ini juga menganalisis hubungan kredit perbankan dengan setiap tipe properti residensial, yaitu: tipe kecil, sedang, dan besar. Hasil uji kointegrasi menggunakan model autoregressive distributions lag (ARDL) menunjukkan adanya hubungan jangka panjang antara kredit dengan harga properti. Sedangkan berdasarkan koefisien jangka panjang menunjukkan bahwa hanya properti tipe kecil yang sensitif terhadap perubahan harga. Hasil analisis lebih lanjut menggunakan vector error correction model (VECM) dan impulse response function (IRF) juga mengindikasikan hubungan jangka pendek yang dinamis antara harga properti dengan kredit dan variabel ekonomi makro. Hasil penelitian ini memberikan implikasi penting bagi stabilitas ekonomi, kebijakan moneter maupun keputusan investasi.
\end{abstract}

Kata Kunci: Harga properti residensial, Kredit, ARDL

\section{PENDAHULUAN}

Sektor properti di Indonesia mengalami pertumbuhan yang cukup pesat seiring dengan meningkatnya pendapatan perkapita masyarakat Indonesia yang diikuti dengan peningkatkan kebutuhan perumahan untuk pemukiman, kegiatan bisnis, maupun investasi. Kondisi ini membuat harga rumah terus mengalamai peningkatan, di mana menurut data Bank Indonesia selama lima tahun terakhir indeks harga properti meningkat rata-rata sebesar $2.97 \%$. Tren kenaikan juga terjadi pada sisi kredit kepemilikan perumahan perbankan, Bank Indonesia (2013) mencatat pertumbuhan kredit kepemilikan rumah sebesar 30,7\% pada tahun 2013. Pertumbuhan yang cukup tinggi pada kedua aspek tersebut membuat kekhawatiran berbagai pihak akan kemungkinan terjadinya bubble pada harga properti, sebagai akibat penyaluran kredit perumahan yang tidak terkendali seperti yang terjadi di Amerika serikat pada tahun 2008.

Hubungan antara harga properti, siklus kredit perbankan, serta kondisi perekonomian telah diobservasi di berbagai negara, di mana hasil penelitian tersebut menunjukkan adanya hubungan signifikan antara properti dan pasar kredit terhadap fluktuasi perekonomian. Perhatian terhadap topik ini menjadi semakin intensif khususnya setelah terjadi krisis kredit perumahan (subprime crisis) di Amerika Serikat yang berpengaruh besar terhadap perekonomian negara-negara lain di dunia. 
Secara teoritis, hubungan antara harga properti dan kredit bank dapat

JURNAL

MANAJEMEN

INDONESIA

Vol. 15 - No. 1

April 2015 berjalan dua arah. Di satu sisi, ketersediaan kredit perbankan dimungkinan akan meningkatkan permintaan terhadap perumahan dan sekaligus meningkatkan harga perumahan, akibat suku bunga kredit yang lebih rendah sebagai sinyal atas ekspektasi kondisi ekonomi yang bagus dan kemudahan likuiditas yang dihadapi oleh rumah tangga (Oikarinen, 2009). Di sisi lain, kenaikan harga rumah juga dapat memacu aktivitas penyaluran kredit perbankan baik dengan cara mendorong suplai atau permintaan kredit (Goodhart \& Hofmann, 2008). Sebagaimana kredit perumahan adalah bagian dari total kredit perbankan, kenaikan harga rumah akan meningkatkan posisi neraca bank seiring dengan upaya mereka untuk menyalurkan kredit. Dengan cara yang sama, ledakan harga rumah juga akan meningkatkan risiko gagal bayar (non-performing loan) yang dihadapi bank, sehingga bank dapat merespon dengan mengurangi penyaluran kredit. Pada saat yang sama, dengan meningkatnya kekayaan yang dirasakan akibat kenaikan harga asset, membuat konstrain yang dimiliki oleh rumah tangga untuk memperoleh pinjaman menjadi menurun, akibatnya permintaan untuk kredit bank akan meningkat. Meskipun hubungan sebab akibat antara pasar perumahan dan kredit telah dijelaskan dengan gamblang, namun kekuatan interaksi antara variabel tersebut masih menjadi subjek pertanyaan empiris.

Sifat interaksi kausalitas antara pasar properti dan kredit memiliki implikasi penting bagi perekonomian. Hubungan antara harga properti dan kredit perbankan diyakini akan memberikan sinyal tentang kondisi keuangan masa depan maupun kemungkinan kemerosotan ekonomi secara agregat. Berdasarkan indikasi tersebut, beberapa pihak menyatakan bahwa penumpukan kredit perbankan dan harga rumah di tahun-tahun terakhir menjelang krisis Asia 1997/1998 merupakan faktor kunci yang berkontribusi menyebabkan krisis pada masa itu (Collyns \& Senhadji, 2002; Inoguchi 2011). Dengan demikian, penyimpangan antara harga rumah dengan kredit perbankan dari nilai fundamentalnya seharusnya mengandung informasi yang berguna bagi pembuat kebijakan dalam merancang kebijakan stabilisasi yang tepat (Goodhart \& Hofmann, 2008). Selain itu, pandangan bahwa kebijakan moneter dapat mempengaruhi kredit perbankan melalui mekanisme transmisi moneter, otoritas moneter harus berhati-hati terkait dengan fluktuasi agregat yang berasal dari tindakan kebijakan yang telah dibuat. Pemahaman tentang siklus harga perumahan dan hubungannya dengan pasar kredit juga penting bagi investor dan perusahaan konstruksi. Misalnya, jika pasar kredit adalah penyebab perubahan harga pasar perumahan, maka ekspansi kredit yang berlebihan oleh perbankan harus diantisipasi sebagai sinyal peringatan bahwa jatuhnya nilai perumahan bisa terjadi dan karenanya harus menjadi faktor dalam keputusan investasi dan konstruksi mereka.

Pada konteks Indonesia, pertumbuhan sektor perbankan paska krisis ekonomi 1997 membutuhkan investigasi terkait dengan interaksi antara kredit dan harga perumahan. Sektor perbankan di Indonesia telah melakukan banyak restrukturisasi diantaranya melalui merger, maupun kebijakan sistem perbankan yang lebih prudent dalam rangka peningkatan stabilitas keuangan. Di sisi lain perkembangan kredit perbankan juga mengalami pergeseran dari sektor bisnis ke sektor rumah tangga khususnya kredit kepemilikan rumah. Peningkatan hutang rumah tangga dan pengaruh yang tinggi sektor properti terhadap bank menarik perhatian terhadap perekonomian Indonesia dan ketahanan sektor keuangan. Penelitian ini akan menguji secara empiris hubungan antara harga rumah dan kredit perbankan di Indonesia dengan menggunakan data kuartalan setelah periode krisis 1997. 
Secara lebih spesifik tujuan dari penelitian ini antara lain adalah, pertama, melihat apakah terdapat hubungan jangka panjang antara harga properti dengan kredit perbankan. Kedua, penelitian ini juga mengevaluasi hubungan jangka pendek antara harga properti dan kredit perbankan. Ketiga, penelitian ini ingin melihat kontribusi setiap segmen properti terhadap kredit perbankan dengan melakukan uji pada data agregat maupun data setiap segmen property. Selanjutnya, penelitian ini akan disusun dalam beberapa bagian, selanjutnya akan membahas landasan teori dan penelitian sebelumnya, diikuti dengan bahasan tengan pendekatan empiris, bagian keempat akan membahas tentang data dan hasil penelitian, dan terakhir adalah bagian kesimpulan.

\section{LANDASAN TEORI}

Harga perumahan, seperti halnya harga asset yang lain ditentukan berdasarkan nilai sekarang dari ekspektasi aliran arus kas masa depan. Peningkatan ketersediaan kredit akan menurunkan suku bunga kredit dan menstimulasi aktivitas ekonomi saat inidan masa depan. Akibatnya, ketersediaan kredit yang lebih baik dapat menurunkan tingkat diskonto dan peningkatan ekspektasi arus kas masa depan yang mengarah pada harga perumahan yang lebih tinggi.

Peningkatan ketersediaan kredit cenderung akan meningkatkan permintaan akan rumah. Pertumbuhan permintaan kemudian akan tercermin dalam harga perumahan yang lebih tinggi sesuai dengan hukum permintaan dan penawaran. Selain itu, utang rumah tangga dapat memberikan informasi mengenai beberapa variabel yang diperkirakan dapat mendorong harga perumahan. Pertama, pinjaman cenderung mencerminkan ketidakpastian pendapatan rumah tangga, semakin tidak pasti tingkat pendapatan suatu rumah tangga, semakin sedikit mereka diperkirakan akan meminjam. Selain itu, adalah wajar untuk mengasumsikan bahwa tingkat bunga saat ini dan ekspektasi tingkat suku bunga masa depan akan mempengaruhi pinjaman rumah tangga. Oleh karena itu, perubahan dalam pinjaman rumah tangga diharapkan dapat memberikan informasi tentang pendapatan dan ekspektasi suku bunga serta pada ketidakpastian pendapatan (Oikarinen, 2009).

Goodhart dan Hofmann (2008) menyebutkan tiga saluran berbeda bagaimana kekayaan harga perumahan dapat mempengaruhi permintaan kredit rumah tangga. Pertama, karena nilai agunan perumahan biasanya tinggi, peningkatan harga perumahan akan melonggarkan syarat pengajuan pinjaman oleh rumah tangga. lacoviello (2004), misalnya, membahas dampak dari peningkatan kekayaan perumahan pada kapasitas pinjaman rumah tangga melalui efek agunan. Leung (2004) memberikan ringkasan dari studi empiris menegaskan pentingnya nilai agunan perumahan. Kedua, perubahan harga perumahan mungkin memiliki efek yang signifikan terhadap persepsi kekayaan rumah tangga, peningkatan kekayaan yang dirasakan menginduksi rumah tangga untuk meningkatkan tingkat konsumsi, sehingga menambah permintaan kredit. Ketiga, pergerakan harga perumahan berdampak pada pasokan kredit melalui apa yang disebut efek neraca. Pertumbuhan harga perumahan meningkatkan nilai modal bank sehingga menambah kemungkinan dan keinginan bank untuk meningkatkan penyaluran kredit.

Beberapa penelitian empiris telah dilakukan untuk menguji hubungan antara harga properti dan kredit perbankan pada berbagai negara. penelitian pada negaranegara maju seperti dilakukan oleh Hofman $(2003,2004)$ dan Goodhart and Hofman (2008). Collyns dan Senhadji (2002) melakukan penelitian pada kasus Hong Kong,
JURNAL

MANAJEMEN

INDONESIA

Vol. 15 - No. 1

April 2015 
Korea Selatan dan Thailand. Gerlach dan Peng (2005) untuk kasus Hongkong. Zhu (2006) pada enam negara Asia, Chen, Tsai, dan Chang (2007) pada kasus di Taiwan, Liang dan Cao (2007) dan Li dan Chand (2013) pada negara Cina, McQuinn dan O'Reilly (2008) pada kasus di Irlandia, dan Inoguchi (2011) dan Ibrahim dan Law (2014) pada kasus di Malaysia, serta masih banyak penelitian lain. Sejauh pengetahuan peneliti, belum ada penelitian terkait hubungan antara harga properti dan kredit perbankan.

Hofmann (2003) melihat hubungan kausal antara kredit dan harga properti di 20 negara maju dan menemukan adanya kausalitas jangka panjang antara harga properti dan kredit perbankan. Sementara itu, Hoffman (2004) meneliti hubungan jangka panjang antara kredit riil perbankan, PDB riil, tingkat bunga riil dan harga real properti di 16 negara-negara industri dengan menggunakan data kuartalan 19801998. Dia menemukan adanya persamaan kredit jangka panjang untuk masingmasing negara, setelah harga properti digabungkan dalam analisis. Dia mencatat bahwa harga properti riil berpengaruh positif dalam persamaan kredit jangka panjang untuk semua negara. Selain itu, berdasarkan analisis persamaan dinamis, perubahan harga properti riil memperoleh respon positif dan terus-menerus oleh kredit bank. Goodhart dan Hofmann (2008) meneliti pola kausalitas antara harga rumah, uang, kredit dan makroekonomi menggunakan vektor autoregresi panel dari 17 negara-negara industri dan data kuartalan antara tahun 1970 - 2006. Mereka menemukan hubungan sebab akibat multi-dimensi antara variabel-variabel tersebut.

Beberapa penelitian juga telah mengevaluasi topik ini pada beberapa negara Asia. Collyns dan Senhadji (2002) menguji secara empiris kontribusi pinjaman bank terhadap inflasi harga properti menggunakan data kuartalan dengan data panel negara Asia yaitu Hong Kong, Korea, Singapura dan Thailand. Indeks harga properti di setiap negara ditentukan bergantung pada kredit untuk sektor swasta dan PDB riil per Kapita. Berdasarkan analisis data panel, diketahui adanya kontribusi yang kuat dari kredit dan PDB riil per kapita terhadap harga properti. Selain itu, dampak dari kredit pada harga properti diketahui lebih kuat selama periode sebelum krisis Asia dan selama periode kenaikan harga properti. Menggunakan metodologi VAR untuk masing-masing negara, ditemeukan hubungan kausalitas dua arah antara harga rumah dan kredit bank untuk semua negara kecuali Thailand. Gerlach dan Peng (2005) menemukan bukti lebih lanjut terkait hubungan antara harga rumah dan kredit bank untuk kasus Hong Kong. Mereka menemukan hubungan kointegrasi antara harga rumah, kredit bank dan PDB riil. Untuk kasus Taiwan, Chen, Tsai, dan Chang (2007) tidak menemukan adanya hubungan jangka panjang antara harga rumah dan pendapatan.

Zhu (2006) meneliti struktur pasarpembiayaan perumahan dan perilaku harga rumah di enam negara Asia yaitu; China, Hong Kong, Indonesia, Korea, Singapura dan Thailand. Dia menemukan hubungan jangka panjang antara harga rumah dan indikator ekonomi makro masing-masing negara. Berdasarkan hasil penelitian tersebut, faktor-faktor yang menjelaskan variasi harga rumah cenderung tergantung pada karakteristik negara dibandingkan dengan pasar pembiayaan perumahan. Kredit bank ditemukan menjadi faktor pendorong yang signifikan di semua pasar kecuali Indonesia, negara dengan sektor perbankan yang kurang maju dibanding negara lain. Selain itu, ada hubungan positif yang kuat antara harga rumah dan harga ekuitas di negara-negara dengan pasar pembiayaan perumahan yang lebih fleksibel, yaitu Hong Kong, Korea dan Singapura. Menariknya, hasil itu juga menunjukkan bahwa PDB tidak mempengaruhi harga rumah di Hong Kong dan berhubungan negatif dengan harga rumah di Korea dan Singapura. 
Di antara penelitian yang telah ada, hanya Zhu (2006) yang memasukkan Indonesia dalam analisa dan menemukan tidak adanya hubungan antara kredit dengan harga properti. Data yang digunakan dalam penelitian tersebut adalah data antara tahun 1990 sampai dengan 2006. Pada masa itu sistem perbankan di Indonesia belum terlalu maju, dan kredit perbankan hanya merepresentasikan $43 \%$ dari produk domestik bruto. Pada saat ini, semenjak krisis ekonomi yang terjadi pada tahun 1997 Indonesia telah merombak sistem dan regulasi perbakannya menjadi lebih kuat dan stabil. Berbagai kebijakan dikeluarkan oleh otoritas perbankan untuk mengendalikan laju kredit salah satunya dengan membatasi rasio loan to value pada rasio tertentu. Selain itu, pertumbuhan ekonomi dan pertumbuhan kredit yang tinggi mungkin akan membuat perbedaan implikasi hubungan antara harga properti dan kredit perbankan. Penelitian ini berkontribusi dengan melihat lebih spesifik pada kasus Indonesia dengan menggunakan data paska krisis Asia.

\section{METODE PENELITIAN}

Penelitian ini menggunakan model auto regressive distribution lag (ARDL) bound test yang dikembangkan oleh Narayan (2004) untuk mengevaluasi hubungan kointegrasi antara harga properti dengan kredit perbankan. Secara teknis prosedur ARDL terdiri dari dua tahapan.Yaitu melakukan uji untuk melihat hubungan jangka panjang antar variabel, diikuti dengan estimasi koefisien jangka panjang maupun jangka pendek. Secara matematis model ARDL yang digunakan dalam penelitian ini adalah sebagai berikut:

\section{Persamaan 1:}

$$
\begin{aligned}
& L L_{t}=\beta_{0}+\beta_{1} L Y_{t}+\beta_{2} L H_{t}+\beta_{3} l_{t}+\varepsilon_{t} \\
& L L_{t}=\beta_{0}+\beta_{1} L Y_{t}+\beta_{2} L H S_{t}+\beta_{3} l_{t}+\varepsilon_{t} \\
& L L_{t}=\beta_{0}+\beta_{1} L Y_{t}+\beta_{2} L H M_{t}+\beta_{3} l_{t}+\varepsilon_{t} \\
& L l_{t}=\beta_{0}+\beta_{1} L Y_{t}+\beta_{2} L H B_{t}+\beta_{3} l_{t}+\varepsilon_{t}
\end{aligned}
$$

Di mana, LL adalah kredit perbankan, LY adalah output real atau tingkat pendapatan yang diukur menggunakan produk domestik bruto (PDB), LH adalah indeks harga property residensial agregat, LHS adalah indeks harga properti tipe kecil, LHM adalah indeks harga properti tipe sedang, LHB adalah indeks harga properti tipe besar, sedangkan I adalah tingkat suku bunga. Semua dinyatakan dalam logaritma natural kecuali suku bunga.

Selanjutnya, masih menurut Narayan (2005) mekanisme error correction untuk model ARDL diestimasikan menggunakan persamaam sebagai berikut:

\section{Persamaan 2:}

$$
\begin{gathered}
\Delta L L_{t}=\delta_{0}+\sum_{i=1}^{p} \varepsilon_{i} \Delta L L_{t-1}+\sum_{i=0}^{p} \emptyset_{i} \Delta L Y_{t-1}+\sum_{i=0}^{p} \varphi_{i} \Delta L H_{t-1}+\sum_{i=0}^{p} \gamma_{i} \Delta I_{t-1}+\lambda_{1} L L_{t-1}+\lambda_{2} L Y_{t-1} \\
+\lambda_{3} L H_{t-1}+\lambda_{4} I_{t-1}+u_{1 t}
\end{gathered}
$$

Langkah pertama penelitian ini menggunakan prosedur bound testing. Bound test digunakan untuk melihat ada tidaknya hubungan jangka panjang antar variabel dalam persamaan (1). Uji hipothesis dilakukan dengan membandingkan standard Wald atau $\mathrm{F}$ statistik. F test memiliki distribusi yang tidak standard yang dipengaruhi
JURNAL

MANAJEMEN

INDONESIA

Vol. 15 - No. 1

April 2015 
JURNAL

MANAJEMEN

INDONESIA

Vol. 15 - No. 1

April 2015 oleh: a) apakah variabel dalam model ARDL adalah I(0) atau I(1); b) jumlah variabel independen; c) apakah model menggunakan intercept dan/atau trend; dan d) jumlah sampel.

Selanjutnya, adalah mengestimasi persamaan (2) dengan teknik ordinary least square (OLS). Model tersebut berdasarkan asumsi bahwa error term tidak terkorelasi, sehingga sangat penting dalam menentukan order lag $p$ yang tepat. Untuk menentukan tingkat lag yang optimal penelitian ini menggunakan kriteria Akaike Information Criterion (AIC)

Dua perangkat critical value dapat dilihat pada Pesaran dan Shin. (2001) yang menyediakan critical value untuk semua jenis regressor baik itu yang murni I(1) maupun yang I(0). Tetapi, critical value disusun berdasarkan ukuran sampel yang terdiri dari 500 dan 1000 observasi dan replikasi 20.000 dan 40.000. Jika nilai F hitung lebih besar dari upper bound dari critical value, maka hipetesis null bahwa tidak ada kointegrasi akan ditolak. Sehingga, null hipotesis tidak ada kointegrasi jangka panjang dirumuskan sebagai berikut diuji dengan alternatif hipotesis .

Pada tahap terakhir dilakukan estimasi variance decompositions (VDCs) yang memungkinkan kita mengukur prosentasi forecast error dari suatu varibel yang di jelaskan oleh variabel yang lain

\section{HASIL DAN PEMBAHASAN}

Penelitian ini menggunakan data time series antara kuartal 1 tahun 2002 sampai dengan kuartal 4 tahun 2013, semua data yang terdiri dari data Indeks Harga Properti Residensial (IHPR), total kredit, Produk Domestik Bruto (PDB) dan suku bunga diperoleh dari website Bank Indonesia. Periode penelitian dipilih berdasarkan ketersediaan data indeks harga properti.

\subsection{Uji stasioneritas data}

Sebagai prasyarat untuk melakukan analisis kointegrasi, langkah pertama yang harus dilakukan adalah melakukan uji stasioneritas data menggunakan uji Augmented Dickey-Fuller (ADF) dan Phillips-Perron (PP). Hasil uji stasioneritas data disajikan pada Tabel 1. Tabel tersebut menyajikan hasil uji statistik pada data level dan data first difference. Seperti yang terlihat pada Tabel 1 seri data level untuk semua variabel tidak dapat menolak hipotesis nol adanya unit root. Berdasarkan hasil uji pada tingkat first difference, hipotesis nol adanya unit root dapat ditolak pada semua variabel yang digunakan dalam penelitian. Dengan demikian, hasil uji stasioneritas dengan model ADF maupun PP menunjukkan hasil yang konsisten menunjukkan bahwa semua variabel terintegrasi pada order 1 , atau disebut sebagail (1).

\begin{tabular}{|c|c|c|c|c|}
\hline & \multicolumn{2}{|l|}{ Level } & \multicolumn{2}{|c|}{ First difference } \\
\hline & ADF & PP & ADF & $\mathbf{P P}$ \\
\hline LH & -0.861 & -1.001 & $-3.911 * * *$ & $-3.978 * * *$ \\
\hline LHS & -0.073 & -0.126 & $-4.454 * * *$ & $-4.438 * * *$ \\
\hline LHM & -0.663 & -0.663 & $-7.220 * * *$ & $-7.221 * * *$ \\
\hline LHB & -1.083 & -0.856 & $-7.243 * * *$ & $-11.336 * * *$ \\
\hline LY & 0.887 & 0.121 & $-2.673 *$ & $-18.138 * * *$ \\
\hline $\mathbf{L L}$ & -2.319 & -2.285 & $-2.652 *$ & $-5.748 * * *$ \\
\hline $\mathbf{I}$ & -2.064 & -1.770 & $-3.624 * * *$ & $-3.037 * *$ \\
\hline
\end{tabular}

Keterangan: Model uji menggunakan constant and trend. $* *, * *$ dan * mengindikasikan signifikansi pada level $1 \%, 5 \%$ dan $10 \%$ secara berurutan. 


\subsection{Uji Kointegrasi}

Dalam melakukan uji kointegrasi, penelitian ini menggunakan pendekatan model ARDL. Ada tidaknya hubungan jangka panjang antara harga properti dengan kredit perbankan dapat dilihat dari nilai $F$ hitung yang dihasilkan dari persamaan. Hasil dari uji menggunakan model ARDL dapat dilihat pada Tabel 2. Seperti yang tampak pada Tabel 2, seluruh model, yang terdiri dari data harga properti secara kesuluruhan/agregat, tipe kecil, tipe sedang, dan besar, memiliki hubungan jangka panjang dengan kredit perbankan. Kesimpulan ini dapat dilihat dari nilai F hitung yang signifikan pada lag 1 sampai 4 untuk semua model yang diuji. Dengan demikian, dapat dikatakan bahwa persamaan harga rumah agregat secara jangka panjang didorong oleh co-movement antara semua jenis harga rumah, variabel makro ekonomi dan kredit bank

\begin{tabular}{ccccc}
\hline \multirow{2}{*}{ Lag-Legth } & \multicolumn{4}{c}{ Computed F-Statistics } \\
\cline { 2 - 5 } & Aggregate & Small & Medium & Big \\
\hline 1 & $4.0471[.008]$ & $3.6599[.013]$ & $4.2756[.006]$ & $2.5634[.054]$ \\
\hline 2 & $3.5563[.016]$ & $2.8660[.039]$ & $3.4514[.019]$ & $2.7592[.045]$ \\
\hline 3 & $3.4141[.022]$ & $3.1059[.032]$ & $2.2006[.097]$ & $3.0675[.033]$ \\
\hline 4 & $4.1084[.012]$ & $4.5195[.008]$ & $3.1861[.033]$ & $5.4267[.003]$ \\
\hline
\end{tabular}

Tabel 2.

Uji Kointegrasi Bounds

Keteragan: critical value bounds diambil dari Narayan (2005) [Case III with unrestricted intercept and no trend and number of regressors $=3]$. Angka di dalam kurung adalah $p$-value.

Koefisien dan pengaruh jangka panjang antara tingkat pendapatan masyarakat, harga properti dan tigkat suku bunga dapat dilihat pada Tabel 3. Tingkat pendapatan (PDB) memiliki pengaruh positif yang signifikan terhadap tingkat penyaluran kredit secara jangka panjang, semakin tinggi tingkat pendapatan masyarakat akan meningkatkan persepsi kekayaan rumah tangga. Peningkatan penghasilan yang dirasakan akan mendorong masyarakat meningkatkan konsumsi sehingga menambah permintaan kredit.

Harga properti memiliki pengaruh negatif terhadap tingkat kredit. Kenaikan harga properti perumahan akan membuat permintaan menurun, penurunan permintaan terhadap properti pada akhirnya akan menurunkan permintaan masyarakat terhadap kredit. Di sisi lain, kenaikan harga rumah juga akan meningkatkan risiko kredit perbankan, sehingga bank mungkin akan berfikir untuk mengurangi penyaluran kreditnya. Tetapi jika dilihat pengaruh harga properti terhadap tingkat kredit perbankan, dari empat model yang di uji, hanya pada properti perumahan tipe kecil saja yang signifikan, sedangkan untuk tipe sedang dan besar pengaruh harga tidak signifikan terhadap kredit. Hasil tersebut mengindikasikan bahwa hanya konsumen pada properti tipe kecil saja yang sensitif terhadap perubahan harga sedangkan permintaan rumah tipe sedang dan besar relatif tidak dipengaruhi oleh pergerakan harga. 
JURNAL

MANAJEMEN

INDONESIA

Vol. 15 - No. 1

April 2015

Tabel 3.

Model Estimasi

Jangka Panjang

Menggunakan ARDL

\begin{tabular}{ccccc}
\hline Regressor & Aggregate & Small & Medium & Big \\
& ARDL $(1,3,0,1)$ & ARDL $(1,3,0,1)$ & ARDL $(1,3,0,1)$ & ARDL $(2,3,0,0)$ \\
\hline C & -23.0689 & -26.2811 & -23.6744 & -24.4736 \\
& {$[-3.8576]^{* * *}$} & {$[-5.4875]^{* * *}$} & {$[-4.4228]^{* * *}$} & {$[-4.5184]^{* * *}$} \\
\hline LY & $\mathbf{3 . 2 8 3 3}$ & $\mathbf{3 . 4 7 8 4}$ & 3.2844 & 3.3185 \\
& {$[7.0387]^{* * *}$} & {$[\mathbf{8 . 6 9 2 4}]^{* * *}$} & {$[7.5118]^{* * *}$} & {$[7.4978]^{* * *}$} \\
\hline LH & $-\mathbf{0 . 8 8 8 2 4}$ & $-\mathbf{- 0 . 8 1 3 1 3}$ & $-\mathbf{0 . 8 0 8 3 5}$ & $-\mathbf{0 . 7 6 9 2 7}$ \\
\hline I & {$[-1.2439]$} & {$[-1.7080]^{*}$} & {$[-1.3233]$} & {$[-1.0641]$} \\
\hline Diagnostic & Adj-R $=\mathbf{0 . 9 9 9 6 4}$ & Adj-R $=0.99966$ & Adj-R $=0.99964$ & Adj-R $=0.99961$ \\
\hline Statistics & DW $=1.7902$ & DW $=1.8574$ & DW $=1.8865$ & DW $=1.9835$
\end{tabular}

Keterangan: $*, * *$ dan $* * *$ menunjukkan level signifikansi pada $10 \%, 5 \%$ dan $1 \%$. Angka di dalam kurung adalah t-hitung. DW adalah uji Durbin-Watson untuk autokorelasi.

Suku bunga kredit (I) memiliki pengaruh negatif terhadap tingkat penyaluran kredit. Secara teori, kenaikan suku bunga akan membuat biaya modal (hutang) semakin tinggi, sehingga akan menurunkan permintaan kredit rumah tangga maupun industri. Di sisi lain, kenaikan suku bunga kredit juga akan meningkatkan risiko kredit macet, sehingga bank akan lebih selektif dalam melakukan penyaluran kredit ke masyarakat.

\subsection{Dynamic analyses}

Mengacu pada hasil uji kointegrasi, selanjutnya dilakukan uji vector error-correction model (VECM) baik pada data agregat maupun data disagregat untuk melihat hubungan timbal balik antar variabel. Untuk tujuan tersebut hubungan sebab akibat antar variabel di uji berdasarkan model Vector Auto Regressive (VAR) dan dalanjutkan dengan simulasi impulse response function (IRF). Menggunakan teknik impulse response function dapat dilihat apakah variabel yang sedang diteliti merespon secara signifikan terhadap shock/pergerakan dari variabel lain. Tabel 4 meyajikan hasil uji Grangger Causality. Gambar 1 menunjukkan generalized impulse response functions hanya untuk data perumahan aggregat. 


\begin{tabular}{|c|c|c|c|c|c|c|}
\hline \multirow[t]{2}{*}{ Dependent variables } & \multicolumn{6}{|c|}{$\chi^{2}$ test statistics of the first differenced terms } \\
\hline & $\Delta \mathrm{H}$ & $\Delta \mathrm{Y}$ & $\Delta \mathrm{L}$ & $\Delta \mathrm{I}$ & & ECT \\
\hline \multicolumn{7}{|c|}{ (a) Aggegate house prices } \\
\hline$\Delta \mathrm{H}$ & - & $3.27313 * *$ & $2.96743 * *$ & 0.74646 & & {$[-1.77992]$} \\
\hline$\Delta \mathrm{Y}$ & 1.00793 & - & 1.37654 & $\begin{array}{l}1.86445 \\
5.5126^{* *}\end{array}$ & & {$[0.11900]$} \\
\hline$\Delta \mathrm{L}$ & 0.54869 & $12.0242 * * *$ & - & & $*$ & {$[-1.10110]$} \\
\hline$\Delta \mathrm{I}$ & $3.06974 * *$ & $3.09808^{* *}$ & $5.69699 * * *$ & - & & [ 4.41077] \\
\hline \multicolumn{7}{|l|}{ (b) Small house prices } \\
\hline$\Delta \mathrm{H}$ & - & $4.21873 * *$ & 2.09615 & 0.45312 & & {$[-1.15961]$} \\
\hline$\Delta \mathrm{Y}$ & 1.22151 & - & $3.28552 * *$ & $\begin{array}{l}0.70709 \\
4.62406^{*}\end{array}$ & & {$[-0.04475]$} \\
\hline$\Delta \mathrm{L}$ & 0.02092 & $17.7641 * * *$ & - & & $*$ & {$[-0.52812]$} \\
\hline$\Delta \mathrm{I}$ & $5.5094 * * *$ & $6.85175^{* * *}$ & $12.0844 * * *$ & - & & {$[4.79224]$} \\
\hline \multicolumn{7}{|c|}{ (c) Medium house prices } \\
\hline$\Delta \mathrm{H}$ & - & $2.14939 *$ & $2.24208^{*}$ & 1.04846 & & {$[-1.70300]$} \\
\hline$\Delta \mathrm{Y}$ & 0.73666 & - & 1.37654 & $\begin{array}{l}1.86445 \\
5.5126^{* *}\end{array}$ & & {$[-0.02793]$} \\
\hline$\Delta \mathrm{L}$ & 0.10663 & $12.0242 * * *$ & - & & $*$ & {$[-0.19304]$} \\
\hline$\Delta \mathrm{I}$ & $2.78582 * *$ & $3.09808^{* *}$ & $5.69699 * * *$ & - & & [4.90359] \\
\hline \multicolumn{7}{|l|}{ (d) Big house prices } \\
\hline$\Delta \mathrm{H}$ & - & $3.85652 * *$ & $3.27758 * *$ & 0.41782 & & {$[-2.68228]$} \\
\hline$\Delta \mathrm{Y}$ & 1.40718 & - & $3.28552 * *$ & $\begin{array}{l}0.70709 \\
4.62406^{*}\end{array}$ & & {$[-0.12775]$} \\
\hline$\Delta \mathrm{L}$ & 0.22583 & $17.7641 * * *$ & - & & $*$ & {$[0.27476]$} \\
\hline$\Delta \mathrm{I}$ & $5.41132 * * *$ & $6.85175 * * *$ & $12.0844 * * *$ & - & & [ 4.34198] \\
\hline
\end{tabular}

Keterangan: $* * *, * *$ dan $*$ menunjukkan signifikansi pada level 1\%, 5\% dan 10\%

Dari Tabel 4 dapat diketahui bahwa secara jangka pendek harga properti residensial dipengaruhi oleh tingkat pendapatan masyarakat $(\mathrm{Y})$. Hasil ini sesuai dengan ekspektasi bahwa naiknya pendapatan akan meningkatkan permintaan terhadap perumahan baik untuk tujuan untuk dihuni maupun investasi, kenaikan permintaan akan direspon dengan naiknya harga. Begitu juga dengan tingkat kredit (L), jika bank semakin ekspansif dalam menyalurkan kredit, masyarakat akan semakin mudah dan murah dalam memeproleh dana, sehingga akan mendorong konsumsi yang salah satunya berakibat pada kenaikan permintaan terhadap properti. Kondisi tersebut terjadi pada semua tipe properti yang diteliti.

Hasil uji Granger Causality pada tabel 4 juga menunjukkan bahwa dalam jangka pendek tingkat penyaluran kredit bank lebih dipengaruhi oleh tingkat pendapatan masyarakat dan tingkat suku bunga. Secara teori tingkat pendapatan yang diukur dengan PDB maupun tingkat suku bunga merupakan sinyal terhadap kondisi ekonomi saat ini maupun masa mendatang, sehingga bank dalam penyaluran kreditnya akan memperhatikan kedua indikator ekonomi tersebut.

Simulasi generalized impulse-response functions (IRF) disajikan pada Gambar 1. Dapat dilihat bahwa harga rumah naik merespon perubahan pada tingkat suku bunga, tetapi menunujkkan nilai yang tidak signifikan dalam responnya terhadap perubahan tingkat kredit. Harga rumah juga menunjukkan respon positif terhadap tingkat pendapatan masyarakat bertolak belakang dengan hasil pada uji kausalitas Granger. Sementara kredit perbankan mempunyai pengaruh yang signifikan terhadap output real. Dari hasil IRF juga terlihat bahwa kredit perbankan merespon negatif terhadap 
JURNAL

MANAJEMEN

INDONESIA

Vol. 15 - No. 1

April 2015

\section{Gambar 1.}

Generalized

impulse-response

functions kenaikan harga perumahan dan kenaikan tingkat suku bunga. Sedangkan kenaikan pada PDB real membuat suku bungan bergerak naik, selanjutnya kenaikan tingkat kredit berpengaruh pada kenaikan tingkat suku bunga.

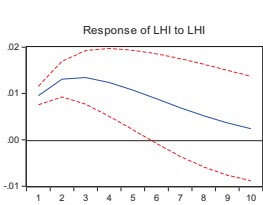

Response to Cholesky One S.D. Innov ations \pm 2 S.E. Response of LLH to LY

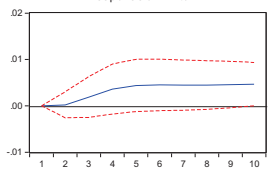
Response of LHI to LLOAN

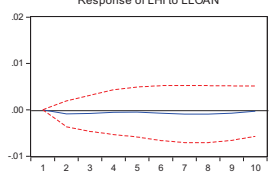

Response of $L Y$ to $L Y$
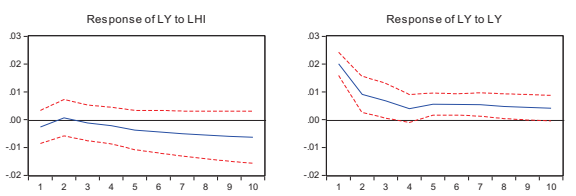

Response of LY to LLO

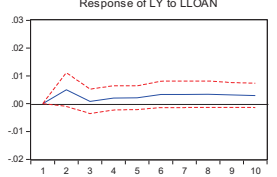

Response of LLOAN toL L
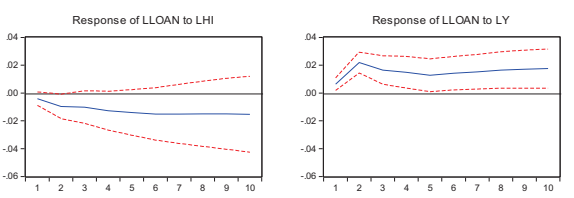

Response of LLOAN to LLOAN

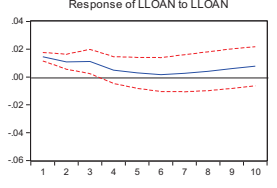

Response of 1 to

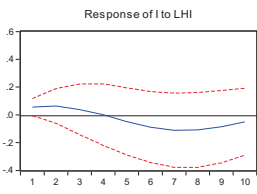

Response of t to LLOAN

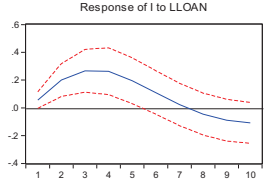

Response of LLH to I

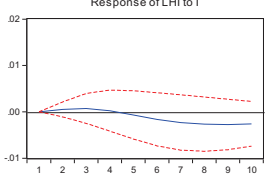

Response of L Y to I

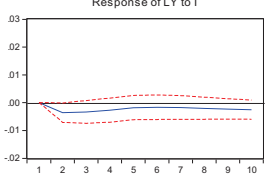

Response of LLOAN to 1

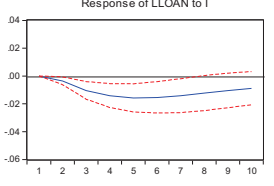

Response of 1 to

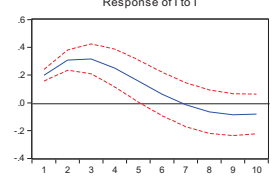

\section{KESIMPULAN}

Penelitian ini bertujuan untuk melihat perilaku hubungan antara harga properti residensial dengan kredit perbankan dan variabel ekonomi makro. Data yang digunakan adalah data kuartalan antara kuarta1 tahun 2002 sampai dengan kuarta 4 tahun 2013. Hasil dari uji kointegrasi menggunakan model ARDL menunjukkan adanya hubungan jangka panjang antara harga properti residensial dengan tingkat kredit perbankan, menariknya jika dilihat lebih detail pada koefisien kointegrasinya hanya properti tipe kecil saja yang signifikan mempengaruhi penurunan kredit. Hasil ini mengindikasikan tingkat sensitifitas konsumen properti tipe kecil terhadap perubahan harga, sedangkan tipe yang lain cenderung tidak dipengaruhi oleh harga. Hasil uji lebih lanjut menggunakan uji Granger Causality maupun impulse response function juga menunjukkan keterkaitan antara harga properti, kredit perbankan, tingkat pendapatan maupun tingkat suku bunga.

Temuan ini memiliki implikasi penting bagi perekonomian maupun bagi bisnis poperti. pergerakan harga rumah dan kredit perbankan akan berisi informasi tentang fluktuasi ekonomi jangka pendek. Selain itu, karena kenaikan suku bunga kemungkinan akan menekan tingkat kredit perbankan, maka otoritas moneter harus mewaspadai implikasi atas kebijakan yang dibuat terhadap harga perumahan maupun terhadap perekonomian. Hasil penelitian ini juga menunjukkan bahwa transmisi kebijakan moneter pada kredit perbankan, yang kemudian berinteraksi dengan harga rumah akan memicu fluktuasi output jangka pendek. Bedasarkan analisis disagregat menunjukkan bahwa pasar rumah ukuran kecil cenderung sensitif terhadap kondisi ekonomi dan tingkat kredit, informasi ini seharusnya penting terutama dalam membuat keputusan investasi perumahan. Akirnya, Hasil penelitian ini diharapkan menjadi perhatian para pemegang otoritas kebijakan moneter untuk memastikan stabilitas ekonomi dan menghindari gejolak seperti halnya krisis subprime mortgage yang terjadi di Amerika Serikat. Selain itu hasil penelitian ini juga bermanfaat bagi para investor dalam membuat keputusan investasi khususnya pada bidang properti. 


\section{DAFTAR PUSTAKA}

Bank Indonesia. 2013. Statistik perbankan Indonesia, Bank Indonesia.

Chen, M.-C., Tsai, I. C., dan Chang, C. O. 2007. House prices and household income: Do they move apart? Evidence from Taiwan. Habitat International. 31(2), 243-256.

Collyns, C., dan Senhadji, A. 2002. Lending booms, real estate bubbles and the Asian crisis. IMF working paper

Gerlach, S. dan Wensheng Peng. 2005. Bank Lending and Property Prices in Hong Kong," Journal of Banking \& Finance, 29 (2), 461-481.

Goodhart, C., dan Hofmann, B. 2008. House prices, money, credit, and the macroeconomy. Oxford Review of Economic Policy, 24(1), 180-205.

Hofmann, B., 2003. Bank lending and property prices: Some international evidence, The Hong Kong Institute for Monetary Research Working Paper No. 22.

Hofmann, B. 2004. The determinants of private sector credit in industrialized countries: do property prices matter? International Finance. 7, 203-234.

lacoviello, M. 2004. Consumption, house prices, and collateral constraints: a structural econometric analysis. Journal of housing economics. 13, 304-320.

Ibrahim, M. H. dan Law, S. H. 2014. House prices and bank credits in Malaysia: An aggregate and disaggregate analysis, Habitat Internationa.I 42 (2014) 111-120.

Inoguchi, M. 2011. Influence of real estate prices on domestic bank loans in Southeast Asia. Asian-Pacific Economic Literature. 25(2), 151-164.

Leung, Charles Ka Yui. 2004. Collateral constraint, the saving rate and relative volatility of housing price, Chinese University of Hong Kong, mimeo.

Li, Q., dan Chand, S. 2013. House prices and market fundamentals in urban China. Habitat International. 40.148-153.

Liang, Qi dan Cao, H. 2007. Property prices and bank lending in China. Journal of Asian Economics. 18, 63-75

McQuinn, K., dan O'Reilly, G. 2008. Assessing the role of income and interest rates in determining house prices. Economic Modelling. 25. 377-390.

Narayan, P. K. 2004. Reformulating Critical Vlues for the Bounds F-statistics Approach to Cointegration: An Application to the Tourism Demand Model for Fiji." Discussion Papers, ISSN 1441-5429. Department of Economics, Monash University, Victoria, Australia.

Narayan, P K. 2005. The Saving and Investment Nexus for China: Evidence from Cointegration Tests. Applied Economics. 37, 1979-1990

Oikarinen, E. 2009. Interaction between house prices and household borrowing: the Finnish case. Journal of Banking and Finance. 33, 747-756.

Pesaran, M. H. dan Shin, Y. 2001. Bounds Testing Approaches to the Analysis of Level Relationships. Journal of Applied Econometrics, 2001, 16.

Zhu, H. 2006. The structure of housing finance markets and house prices in Asia. BIS Quarterly Review. 55-69. 
JURNAL

MANAJEMEN

INDONESIA

Vol. 15 - No. 1

April 2015

Jurnal Manajemen Indonesia 